\title{
Subsidized work before and after the German Hartz reforms: design of major schemes, evaluation results and lessons learnt
}

\author{
Joachim Wolff ${ }^{*}$ and Gesine Stephan ${ }^{2}$
}

\author{
* Correspondence: \\ Joachim.Wolff@iab.de \\ ${ }^{1}$ Institute for Employment Research, \\ Regensburger Str. 104, 90478 \\ Nuremberg, Germany \\ Full list of author information is \\ available at the end of the article
}

\begin{abstract}
This review discusses empirical studies on hiring subsidies in the private sector and on schemes directly providing usually public or non-profit sector jobs for the unemployed in Germany. An important effect of hiring subsidies is that they stabilise employment. For employment schemes, results before the Hartz reforms imply mostly negative average treatment effects on regular employment outcomes of the treated, while results are mostly positive after introducing the reforms. During the years 2003 to 2005, the benefit system was radically reformed and now emphasizes mutual obligations. That might be one reason for changes in the effectiveness of job creation schemes.

JEL codes: H53; J08; 168

Keywords: Hiring subsidies; Job creation schemes; Evaluation of active labour market programmes
\end{abstract}

\section{Introduction}

High and persistent unemployment was a major challenge for German policy makers at the start of the millennium. In recent years, Germany's unemployment rate declined considerably. Policies aimed at increasing employment prospects of unemployed people might have contributed to this development. Moreover, these policies are important to support groups of unemployed people in particular need of assistance. An important element of active labour market programmes (ALMPs) is subsidized work. In Germany, hiring subsidies for employers exist to re-integrate unemployed persons into work, though these are rarely used to hire the most disadvantaged among the unemployed. Programmes that mainly subsidize jobs in the public and non-profit sector in contrast help to create work opportunities for unemployed people with severe employment impediments. They also aim at improving subjective well-being and social inclusion.

Recent meta-studies provide some general insights on the effectiveness of ALMPs. Card et al. (2010) took 199 programmes into consideration that were investigated in studies on 26 countries. They studied classroom and on-the-job training, job search assistance and sanctions for failing to search, subsidized private sector employment, subsidized public sector employment, and combinations of these policies. Their results imply that subsidized public sector employment is relatively ineffective. Subsidized private sector employment tends to be less effective than classroom or on-the-job training

(c) 2013 Wolff and Stephan; licensee Springer. This is an Open Access article distributed under the terms of the Creative Commons Attribution License (http://creativecommons.org/licenses/by/2.0), which permits unrestricted use, distribution, and reproduction in any medium, provided the original work is properly cited. 
and job search assistance or sanctions for failing to search. The meta-study by Kluve (2010) investigated studies on 137 programmes in 19 European countries. Its findings confirm public sector employment schemes as the least effective and even as a detrimental programme. Wage subsides, services, and sanctions tend to be effective, as are training programmes though with more modest effects.

Even though these meta-studies provide some important conclusions, a country specific survey is an important addition to the literature. It allows making statements for a specific institutional and socio-economic background. In particular, it helps to determine whether changes in ALMPs and the related institutional framework are important candidates for explaining changes in the effectiveness of programmes. We discuss results and lessons learnt from programme evaluations of hiring subsidies as well as (mainly) public and non-profit sector employment programmes in Germany. We will not discuss early studies, which were concerned with programme impact in East Germany during the transition process of the 1990s. Their impact during transition is a very specific topic. Our interest is on studies investigating the period just before and after the major labour market reforms of the years 2003 to 2005, the four so called Hartz reforms. These reforms considerably altered the unemployment benefit system and introduced new ALMPs including new programmes that create subsidized jobs for very disadvantaged unemployed people.

In a nutshell, the literature indicates that hiring subsidies for workers with placement difficulties at least have the potential to integrate individuals into the labour market for a longer period than could have been expected without subsidization. The Hartz reforms hardly modified this instrument. This is different for programmes that create subsidized jobs for more disadvantaged unemployed workers: The Hartz reforms introduced important new schemes that were more strongly targeted at people with severe placement impediments. For the period before the Hartz reforms, detrimental average treatment effects on the regular employment rate of job creation scheme participants dominate the available results. For a number of different schemes though, some positive effects are found in the period after implementing the reforms. All in all, there is substantial evidence that careful targeting and implementation is essential if employment programmes are to improve and not worsen labour market prospects of participants.

The paper is structured as follows. In the next section, we briefly discuss the main effects that can be expected from ALMPs according to relevant theories, and introduce the main methods used in the available evaluation studies. Section three outlines the design and goals of programmes under consideration in Germany. In Section four we discuss the studies on hiring subsidies and job creation schemes in Germany. The final Section five summarizes and draws some key conclusions for policy-makers. Moreover, it turns to important topics for futures evaluation studies.

\section{Theoretical considerations and empirical methods applied}

Targeted hiring subsidies are tailored to unemployed persons who are still able to find subsidized private sector jobs. They are typically granted for a limited time period. Their aims are at least twofold: First, they should motivate a firm to hire a particular unemployed person for a particular job as the subsidy reimburses the firm for a factual or perceived gap between the wage and productivity of the hired person. This might be 
useful if minimum wages or collectively negotiated wages drive a wedge between initial individual productivity and wages. Second, subsidies might in the longer term raise tenure of a subsidized worker if an initial skill mismatch diminishes with training on the job. Furthermore, an employer's uncertainty about an applicant's productivity will be reduced during the subsidized employment period.

In contrast, the main aim of job creation schemes is to improve the labour market prospects of unemployed persons who cannot be re-integrated into the regular labour market immediately (even with the help of a hiring subsidy). They work through a number of channels (Hohmeyer and Wolff 2012): Participants accumulate or refresh their human capital including basic skills like managing a daily work schedule. Participation might signal willingness to work. Already due to the possibility of participation, the schemes might raise search efforts ex ante and decrease reservation wages as participation reduces leisure time and time available to engage in the shadow economy. Ex post, participants might be locked into the programme as they have less time and incentives to search for work. Apart from improving employability, the goal of enhancing social inclusion of the most disadvantaged unemployed plays a considerable role for policy makers.

In simple static labour demand models, a hiring subsidy reduces an employer's labour cost (Bell et al. 1999); public employment provision might have the same effect. If subsidies exceed productivity deficits of subsidized workers they lower total factor costs. If these are not passed on to consumers, the subsidy shifts the labour demand curve upwards; employment as well as the wage rate increases, depending on the wage elasticities of labour demand and supply. In case of a minimum wage, a subsidy might induce firms to hire more low productivity workers just at the threshold, without actually increasing wages. An adverse direct effect arises, however, if employers perceive eligibility for a subsidy or programme participation as a negative signal, which stigmatizes workers. Within a search and matching framework, wage subsidies might increase job creation as well as job destruction, depending on their particular design (Pissarides 2000, Chap. 9).

Calmfors (1994) discusses the effects of ALMPs within a wage-setting and labour demand framework. As mentioned earlier, subsidies can reduce wage costs and thus shift the labour demand curve upwards and increase employment. However, non-intended effects might emerge: A deadweight loss occurs if some subsidized workers would have been recruited without the subsidy. Targeted wage subsidies might also have indirect effects on non-participants. First, substitution effects prevail if some of those taking up subsidized jobs will merely replace other workers within the same firm. Second, displacement effects may arise if employment in some firms increases due to the subsidy, but at the expense of jobs in other firms. Fay (1996), however, makes the point that substitution and displacement effects may not be considered that important from a policy perspective, since targeted subsidy schemes are intended to "shuffle the queue" of job-seekers: Subsidies targeted at the long-term unemployed may lead employers to hire them instead of other unemployed persons.

Wage subsidies might shift the wage-setting curve further upwards (c.p. increasing unemployment, see Calmfors 1994) if subsidies are quantitatively important enough to lessen labour market pressure. Similarly, a widespread use of subsidies can increase an individual's reservation wage (Adda et al. 2007). Moreover, additional taxes or 
contributions to finance the programmes negatively affect demand for goods and services and in turn for (unsubsidized) labour. Hence, even if beneficial micro effects exist, the aggregate programme impact might still be negative.

A large number of empirical studies investigated effects of participation in hiring subsidies and different schemes directly providing jobs on selected outcomes, in particular on unsubsidized contributory (regular) employment. The samples were usually drawn from administrative records.

For Germany, no field experiments on subsidized work have been conducted yet. A few studies utilize natural experiments to analyse the effect of changes in legislation or eligibility thresholds on the group of eligible individuals, applying difference-indifferences or regression discontinuity approaches (Imbens and Angrist 1994). The vast majority of the studies cited, however, is non-experimental. A small number of these studies apply duration models (Abbring and van den Berg 2003), while most of them rely on statistical matching methods to choose a comparison group with a distribution of characteristics similar to that observed for the participant group (Rubin 1974). The studies mainly applied propensity score matching (PSM) to compare programme participants with suitable non-participants, for whom similar participation probabilities had been estimated (Rosenbaum and Rubin 1983). Statistical matching methods rely critically on the conditional independence assumption. This non-testable assumption requires the observation of all variables that determine selection into the programme as well as the outcome in the case of non-participation.

A smaller literature quantified effects of hiring subsidies and job creation schemes on the entire labour market or was concerned with deadweight loss, substitution or displacement effects. These studies worked with regional or company data and mainly suitable (dynamic) panel regression methods. One of the main outcomes that they take into account is a job-seeker rate that does not only consider unemployed people as jobseekers but also participants in ALMPs, who are often not registered as unemployed in official statistics. The key reason for this choice is to avoid bookkeeping effects, as unemployed people entering ALMPs would automatically reduce the unemployment rate but not the job-seeker rate. When modelling the effects of the intensity of a labour market programme on the job-seeker rate with regional data for instance, the models have to allow for lagged dependent variables and need to take into account a simultaneity problem. The job-seeker rate is affected by the programme intensity. Yet the programme's intensity results from a policy reaction function that depends on the job-seeker rate. To resolve the related identification problems differenced Generalized Methods of Moments (GMM) estimators (Arellano and Bond 1991), system GMM estimators (Blundell and Bond 1998), or a transformed Maximum Likelihood Estimator (Hsiao et al. 2002) are often applied. Moreover, some studies address the issue that job-seekers not only search in their own but also in neighbouring regions. In turn the methods need to take regional correlation into account.

\section{Institutional framework and design of major schemes}

The German unemployment compensation system consists of unemployment insurance benefits, financed mainly through contributions of workers and firms, and tax funded basic income support for needy unemployed persons. The unemployment insurance benefit amounts to 60 or 67 per cent of the previous wage (for people without 
or with dependent children), while the duration varies with the worker's employment history. Until 2005, unemployed persons passing a means-test received unemployment assistance for an unlimited period after exhausting their unemployment insurance benefit. The benefit level was 53 or 57 per cent of their last net earnings, again dependent on whether or not the recipient had children. Without access to these benefits or if previous earnings were too low to sustain the household, unemployed people had to rely on the flat rate and means-tested social assistance.

The Hartz IV reform in 2005 replaced these two means-tested benefits by one (mainly) flat rate welfare benefit, which was labelled unemployment benefit (UB) $\mathrm{II}^{1,2}$. At the same time the insurance funded benefit was labelled as UB I. The new UB II consists of several parts. The most important ones are a) a benefit to cover costs of accommodation and heating (job centres have some degrees of freedom in determining these) and b) a basic cash benefit to cover other regular expenditures. In the year 2013, the latter amounted to 382 Euro a month for a single-adult household. For multiperson households, the law takes into account lower needs of children and economies of scale. The UB II level constitutes an implicit minimum wage. Cichorek et al (2005) show that it was around 3.7 Euro per hour for single households, but more than 9 Euro per hour for households with one main-earner and two children in the year 2005. Müller and Steiner (2009) present estimates of the implicit minimum wage for 2008 and find a range from about 4.5 up to not much more than 9 Euro per hour. For former social assistance recipients the introduction of the UB II implied no major financial changes (Blos and Rudolph 2005). For former unemployment assistance recipient households, household income including transfers could become higher or lower. Based on the German survey on income and consumption, Blos and Rudolph (2005) showed in a simulation study that about 17 per cent of former unemployment assistance recipient households would not have passed the means-test for UB II. Of those who would have qualified for the new benefit, 53 per cent would have achieved a lower income under the new system.

For benefit recipients who are capable of working, the Hartz reforms implied considerable changes. They made benefit receipt more conditional on job search effort, extended job search requirements and reduced the potential duration of unemployment insurance benefits for older age-groups. Moreover, the new regime requires availability for work and for ALMPs from all members of a welfare recipient household who are capable of working. The reforms were also meant to improve the quality of public employment services (PES) and to increase support provided to job seekers. They extended the set of ALMPs and partly modified existing schemes and raised the inflow into these schemes. Jacobi and Kluve (2007) provide a more detailed discussion of the Hartz reforms. Finally, it should be noted that responsibilities for the counselling and the funding of programme participation for non-benefit recipients lie with the insurance branch of the PES.

\subsection{Hiring subsidies}

Hiring subsidies ("Eingliederungszuschüsse", Articles 88-92, 131 Social Code III) can be claimed by employers recruiting unemployed persons with placement difficulties, to compensate the firm for productivity deficits of the worker. The current main scheme can account for up to 50 per cent of the monthly wage or salary and continue for at 
most 12 months. Caseworkers in local employment agencies have latitude in the decision to grant the subsidy and in fixing its amount and duration. A subsidy cannot be granted if the worker was employed regularly at the firm applying for the subsidy during the last four years, or if another employee was dismissed to hire a subsidized worker instead. Only wages up to the collectively negotiated or the local customary level, respectively, and up to social security thresholds can be taken into account when determining the size of the subsidy. A particularly important feature of the German scheme is the protection period associated with subsidization: If a subsidized person with the exception of disabled persons - is dismissed during the subsidization or a follow-up period of the same length for reasons attributable to the employer, the employer could be asked to reimburse up to half of the subsidy. Until 2011, however, this follow-up period was not applied for particular subsidy variants for older and younger workers (discussed below).

While major programme features have remained unchanged during the last decades, several details have been modified. In particular, previous variants of the scheme have been merged and other variants have been newly introduced over time (and merged again). In the following we describe major developments. We do not discuss an important, but quantitatively less prominent variant for disabled people. From 1998 to 2003, three major variants of hiring subsidies were in place. The first was characterized by a low level of targeting, compensating for special training requirements, while the second was aimed at unemployed persons with severe employment impediments (like longterm unemployment). A third variant could be granted to unemployed persons aged 50 and older. The Hartz III reform in 2004 merged these variants into one subsidy (that is still in place today and is described above) for people with placement difficulties. Employers can obtain such subsidies when hiring unemployed persons receiving UB I, UB II or without benefit receipt. Extensions can be granted for handicapped or older workers. During the years 2007 and 2008, four additional variants were introduced that targeted older and younger workers. In April 2012, however, three of them were abolished again (only one additional variant targeted at older workers remains).

Over the years, several specialized schemes were in place which could substitute the main variant of hiring subsidies. Of particular importance was the so called BHI scheme ("Beschäftigungshilfen für Langzeitarbeitslose"), which targeted long-term unemployed people from 1989 until 2002. The subsidy covered 60 (40) per cent of a standardized wage rate during the first (second) half year of employment.

\subsection{Job creation schemes and workfare}

Job creation schemes aim at the hardest-to-place unemployed; they can be accompanied by other components like training components or some consulting by social workers. We label the oldest scheme that had been in place since 1969 the traditional job creation scheme ("Arbeitsbeschaffungsmaßnahmen", Articles 260-271 Social Code III). It was modified several times after the year 2000. Until 2001, it was limited to long-term unemployed people and people who were not yet long-term unemployed but within the last 12 months were for at least six months registered as unemployed with the PES. Since 2003, however, all unemployed people who were unable to get a job otherwise could be placed into the programme irrespective of unemployment duration. In the early 2000 s the scheme was intended to stabilise disadvantaged unemployed persons, to provide them 
with some training, and improve their prospects to work in regular jobs. These goals were altered somewhat in 2004: The scheme since then aimed to help stabilise participants' employability and to reduce high unemployment in occupational or regional labour markets.

The potential duration of participation was principally limited to a maximum of 12 months, but could be longer in exceptional cases. To avoid repeated participation, since 2004 a new spell in a job creation scheme could only start if a person had not already participated during the last three years. Starting in 2003, the subsidized jobs were exempt from unemployment insurance contributions, in order to preclude the possibility of renewing eligibility for unemployment insurance benefits by participating. The subsidy paid to the organizer of the scheme or employer also changed. Prior to 2004 it was related to the wage; since 2004 maximum lump-sum payments were defined for full-time participants according to their qualification. The maximum monthly lump-sum ranged from 900 Euro for participants with no occupational qualification up to 1,200 Euro for participants with a university degree (exemptions were possible). For additional costs of working or of qualifying the participant the PES could grant a supplementary subsidy of up to 300 Euro a month.

As part of the Hartz IV reform two mandatory work opportunity programmes ("Arbeitsgelegenheiten", Article 16d Social Code II) were introduced for UB II recipients who without this support could not be integrated into work ${ }^{3}$. In the quantitatively more important scheme, participants work in public or non-profit sector jobs and should not perform tasks of regularly employed workers to avoid the loss of regular jobs. Employers receive a monthly lump-sum payment to cover their programme costs. Participants receive welfare benefits and one to two Euros per hour worked to compensate them for costs of working. Therefore, the programme is often called "One-Euro-Jobs". It aims at improving participants' employability. It can be regarded as a workfare scheme as participation is mandatory and welfare recipients essentially work for their welfare benefit. In financial terms the scheme is not very attractive for welfare recipients and regular part-time jobs would usually be preferable to One-Euro-Job participation, due to earnings disregards of the welfare benefit system. The work obligation of the welfare system and the related potential One-Euro-Job participation might influence the welfare recipients' job search behaviour through a threat effect. Some welfare recipient might therefore reduce their reservation wages and raise their search effort, in order to avoid participation.

Participants in the second work opportunity programme, which was quantitatively much less important than One-Euro-Jobs, were assigned to jobs that could compete with regular ones and did not necessarily need to be in the public interest. Unlike OneEuro-Jobs, the programme focused on integrating participants into regular work. Participants received regular earnings, so that we call the programme wage-paying work opportunities. Since the year 2009, they no longer paid unemployment insurance contributions, to preclude the possibility for participants to become eligible for unemployment insurance benefits on the basis of their programme participation. Employers received a monthly lump-sum payment to cover their cost of operating the scheme including a compensation for the difference between the wage and the productivity of a participant. Participation in work opportunities usually lasted less than a year and frequently three to nine months (DataWareHouse of the Statistics Department of the Federal Employment Agency). However, there were no limits on the time participants 
could spend in one or several work opportunity spells. In April 2012 the wage-paying work opportunities and the JobPerspective (discussed below) were replaced by the promotion of employment relationships ("Förderung von Arbeitsverhältnissen", Article 16e Social Code II). Its eligibility criteria are similar to those of the JobPerspective. However, for the new programme a limit of two years of participation within a five year period after the start of the first of a number of subsequent programme spells was introduced.

The JobPerspective ("Beschäftigungszuschuss", Article 16e Social Code II) was introduced in October 2007. This employer subsidy aimed at providing work opportunities to improve social inclusion of welfare recipients who were long-term unemployed and were characterized by at least two other severe employment impediments. The scheme offered a subsidy of up to 75 per cent of the wage to the employer. The first employment phase was 24 months. Thereafter, under certain circumstances the subsidy could be granted permanently to integrate a participant into work. This generous subsidy was supposed to be granted only if a welfare recipient had already gone through an activation phase of six months and was still very unlikely to find work within the next two years.

\subsection{Importance of the programmes during the period 2000 to 2012}

We finish this section by briefly discussing the development of the inflow into the schemes described and into further major labour market schemes in Germany over time. Moreover, we also present the aggregate expenditures on the programmes. The inflow into hiring subsides ranged from about 125,000 in 2001 to 280,000 during the period 2007 to 2009 (Table 1). Expenditures were lowest in the year 2005, shortly after the Hartz IV reform (Table 2). It was a year with a very low inflow into hiring subsidies. Even though in the period after 2005 the inflow into hiring subsidies tended to be higher than in the period 2000 to 2004, the expenditures were nevertheless considerably lower after 2005. This was partly due to a shortening of the average duration of subsidization (Figure 1). From 2000 to 2005 the average duration was about eight to nine months, while after 2005 it was rather five to six months.

None of the job creation schemes under consideration was in place over the entire observation period. Entry rates into the traditional job creation scheme fell from 264,000 in the year 2000 to about 11,000 in 2009 (Table 1). It was abolished in April 2012 due to pessimistic results from evaluation studies on its effects and small participant numbers. However, by the introduction of the One-Euro-Job scheme wage-paying job creation was partly replaced by workfare, with an on average shorter programme duration (Figure 1). One-Euro-Jobs constitute a large scale programme with an annual inflow of more than 700,000 people in the period 2006 to 2009 (Table 1), but inflows halved until the year 2012. For the wage-paying job creation (the traditional job creation scheme, wage-paying work opportunities, and the JobPerspective) taken together, inflows ranged from 104,000 to about 155,000 in the period 2003 to 2009. Thereafter, a sharp decline of their importance can be observed. The JobPerspective for people with extreme difficulties of finding jobs was the smallest of all direct job creation schemes with annual inflow that never exceeded 27,000 (Table 1). The much lower inflow into different job creation schemes and One-Euro-Jobs at the end of the observation period was partly a result of a considerable decline in unemployment. However, it was also a 
Table 1 Inflow into major German labour market schemes and unemployment stock in Germany since the year 2000 (in thousand)

\begin{tabular}{|c|c|c|c|c|c|c|c|c|c|c|c|c|c|}
\hline & 2000 & 2001 & 2002 & 2003 & 2004 & 2005 & 2006 & 2007 & 2008 & 2009 & 2010 & 2011 & 2012 \\
\hline \multicolumn{14}{|l|}{ Subsidized work } \\
\hline Hiring subsidies (without BHI) & 152 & 127 & 188 & 183 & 171 & 143 & 234 & 278 & 282 & 277 & 252 & 198 & 153 \\
\hline BHI subsidies & 44 & 50 & 29 & & & & & & & & & & \\
\hline Traditional job creation scheme & 264 & 192 & 162 & 141 & 149 & 78 & 83 & 70 & 70 & 11 & 3 & 1 & \\
\hline One-Euro-Jobs & & & & & & 603 & 796 & 777 & 769 & 723 & 660 & 436 & 343 \\
\hline Wage-paying work opportunities & & & & & & 26 & 40 & 41 & 59 & 93 & 80 & 39 & \\
\hline JobPerspective & & & & & & & & 1 & 25 & 27 & 8 & 3 & \\
\hline \multicolumn{14}{|l|}{ Promotion of employment relationships } \\
\hline \multicolumn{14}{|l|}{ Other major schemes } \\
\hline Start-up subsidies ${ }^{\mathrm{a}}$ & 93 & 96 & 125 & 254 & 351 & 265 & 218 & 158 & 144 & 157 & 163 & 145 & 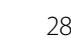 \\
\hline Further vocational training & 523 & 442 & 455 & 255 & 185 & 132 & 264 & 365 & 463 & 618 & 487 & 305 & 300 \\
\hline Short-term training & 485 & 551 & 865 & 1064 & 1188 & 895 & 28 & 1087 & 1202 & 479 & & & \\
\hline Activation and integration measures ${ }^{b}$ & & & & & & & & & & 1194 & 1621 & 1201 & 1113 \\
\hline Average unemployment stock & 3880 & 3859 & 4072 & 4381 & 4388 & 4861 & 4487 & 3760 & 3259 & 3415 & 3238 & 2976 & 2897 \\
\hline
\end{tabular}

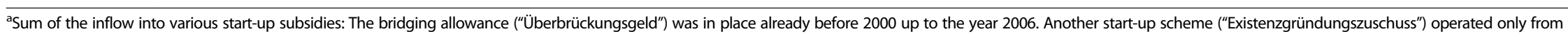
2002 to 2006. Both were replaced by the scheme "Gründungszuschuss" in August 2006. Moreover, a forth scheme ("Einstiegsgeld") for UB II recipients is available since 2005.

${ }^{\mathrm{b}}$ This programme replaced short-term training and schemes for contracting out placement services (not displayed in the table).

Source: Datawarehouse of the Statistics Department of the German Federal Employment Agency. 
Table 2 Annual spending on major German labour market schemes since the year 2000 (in million Euro)

\begin{tabular}{|c|c|c|c|c|c|c|c|c|c|c|c|c|c|}
\hline & 2000 & 2001 & 2002 & 2003 & 2004 & 2005 & 2006 & 2007 & 2008 & 2009 & 2010 & 2011 & 2012 \\
\hline \multicolumn{14}{|l|}{ Subsidized work } \\
\hline Hiring subsidies (without $\mathrm{BHI})^{\mathrm{a}}$ & 980 & 1062 & 1225 & 1349 & 908 & 454 & 611 & 826 & 942 & 1049 & 895 & 665 & 473 \\
\hline Traditional job creation scheme & 3680 & 2976 & 2333 & 1676 & 1212 & 616 & 578 & 513 & 513 & 206 & 37 & 13 & 2 \\
\hline One-Euro-Jobs & & & & & & 895 & 1127 & 1020 & 1034 & 1044 & 1006 & 596 & 358 \\
\hline Wage-paying work opportunities & & & & & & 1104 & 1386 & 1319 & 1406 & 1678 & 1679 & 896 & 446 \\
\hline JobPerspective & & & & & & & & 1 & 136 & 460 & 471 & 212 & 79 \\
\hline Promotion of employment relationships & & & & & & & & & & & & & 10 \\
\hline \multicolumn{14}{|l|}{ Other major schemes } \\
\hline Start-up subsidies ${ }^{\mathrm{b}}$ & 750 & 805 & 1006 & 1681 & 2727 & 3200 & 2581 & 1862 & 1835 & 1608 & 1925 & 1733 & 905 \\
\hline Further vocational training & 2680 & 2778 & 2705 & 2029 & 1440 & 1222 & 988 & 1138 & 1459 & 2066 & 1788 & 1471 & 1247 \\
\hline Short-term training & 323 & 350 & 478 & 578 & 496 & 335 & 330 & 305 & 345 & 213 & & & \\
\hline Activation and integration measures $^{c}$ & & & & & & & & & & 392 & 908 & 638 & 519 \\
\hline
\end{tabular}

${ }^{\text {Figigures on BHI are not available. }}$

"Programmes as described in note b of Table 1. Figures on a small scale programme "Einstiegsgeld" for UB II recipients are not available for 2005 and 2006. 'See note b of Table 1.

Source: Statistics Department of the German Federal Employment Agency (Eingliederungsbilanzen). 


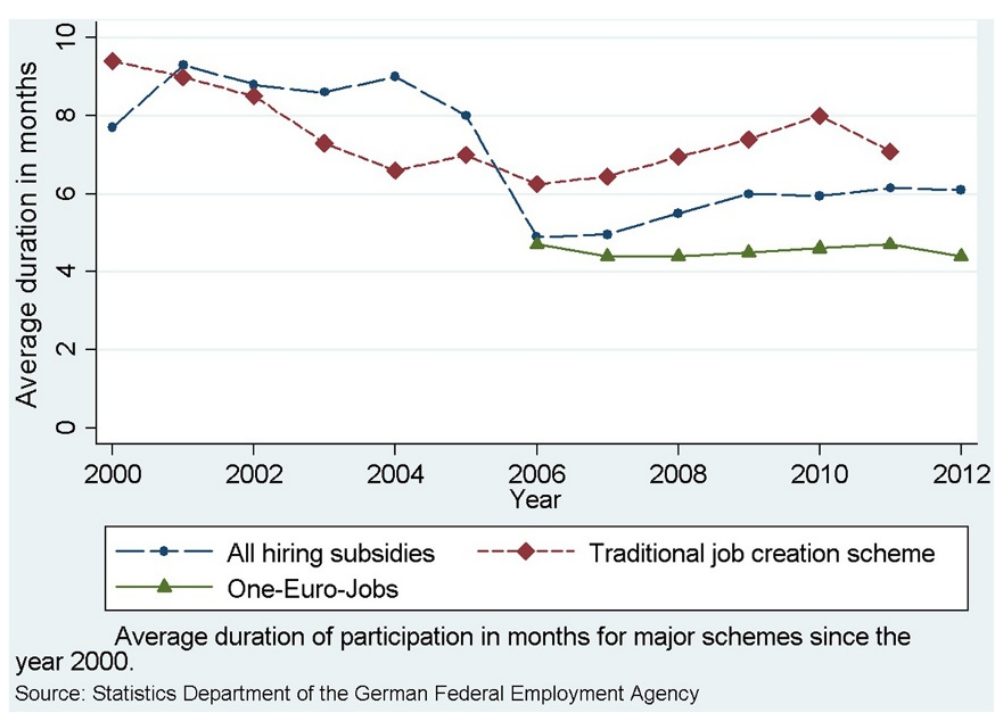

Figure 1 Average duration of participation in months for major schemes since the year 2000.

reaction of policy-makers to results on their effectiveness that suggested concentrating the subsidies more on hard-to-place people. Moreover, it reflected a need to cut public spending, once the great recession was over.

How do entries and expenditures into subsidized work compare to other main labour market programmes? In our observation window, several financial start-up subsidies were in place, to encourage entrepreneurship among the unemployed. During most years, take-up rates of such start-up subsidies were lower than for hiring subsidies, and remained below entries into the large employment programmes (Table 1). In terms of spending, however, start-up subsidies were one of the most important schemes (Table 2). Again in terms of inflow, further vocational training ("Berufliche Weiterbildung", Articles 81-87 Social Code III) and short-term training (in classrooms and firms, "Eignungsfeststellungs- und Trainingsmaßnahmen, Articles 48-52 Social Code III) were often more important than employer subsidies and short-term training was partly more important than job creation and workfare taken together. Short-term training participations lasted, however, no more than a few weeks. In 2009, short-term training was replaced by new activation and integration measures ("Maßnahmen zur Aktivierung und beruflichen Eingliederung", Article 45 Social Code III), which also encompass contracting out placement services to private providers.

\section{Evaluation results}

The majority of microeconometric studies presented below are based on administrative data on individual periods of unemployment benefit receipt, registered job search, registered unemployment, participation in ALMPs and contributory or minor employment. Most recent studies utilize excerpts from the Integrated Employment Biographies (IEB) of the Institute for Employment Research, which was developed in the course of the Hartz evaluation. Access to a sample is possible through the research data centre of the Federal Employment Agency (Dorner et al. 2010). For conducting programme evaluation studies, these data offer many relevant dependent variables (like periods of regular employment) and allow controlling for a wide range of socio-demographic characteristics, individual 
labour market history, and the regional labour market situation. Studies analysing aggregate effects of ALMPs with regional units like districts or local labour agencies rely on the same administrative data aggregated at the regional level. These regional data are available at the Statistics Department of the Federal Employment Agency.

\subsection{Hiring subsidies}

Why do firms use hiring subsidies? Hartmann (2004) conducted a comprehensive study of the importance of a wide range of wage subsidy variants for firms and their hiring behaviour. Case studies showed that flexibility requirements and uncertainty about their labour demand in the longer run particularly deterred firms from using subsidies (p. 51 f.). Based on a firm survey related to 3,500 subsidized hires, Hartmann found that the main integration problem of hard-to-place workers were ascribed (not observed) productivity deficits (p. 147). Moreover, regarding hiring subsidies, firms answered that they would have hired around 40 to 60 per cent of subsidized persons without receiving the subsidy (p. 93). This share is smaller for workers with severe obstacles to reintegration. However, as firms retrospectively assessed their subsidized workers and not before hiring them these figures cannot directly be interpreted as deadweight effects. Hartmann's results were reinforced by later findings (Brussig et al. 2008; Brussig and Schwarzkopf 2011). These studies also showed that for the most part, employers took the initiative and negotiated with the local labour agency over a subsidy for hiring a particular unemployed worker.

Early quantitative research on the effectiveness of subsidization on the subsidized was based on PSM methods, using similar unemployed persons as a comparison group. This approach estimates a mix of two effects: The effect on the hiring decision of a firm and the effect on labour market outcomes once the hiring has taken place. Thus - in spite of a careful choice of comparison persons - estimated effects may be partly composed of deadweight effects.

Jaenichen $(2002,2005)$ analysed entries into hiring subsidy schemes and into the BHI scheme during the year 1999. Three years after programme entry her results imply positive effects on the participants' shares in unsubsidized employment of around 20 to 40 percentage points, but a considerably lower reduction of their unemployment rate as comparison persons withdraw from the labour market more often. Similarly, people taking up a subsidized job during the first two quarters of 2002 were investigated as part of the Hartz evaluation (Jaenichen and Stephan 2011, ZEW et al. 2006). Three years after the start of the subsidy, 40 to 70 per cent of recipients were in regular employment and their employment rate was 20 to 40 percentage points higher than for the comparison group of similar unemployed persons. Again, effects in terms of avoiding unemployment were much lower. In particular older unemployed comparison persons in West Germany seemed to use retirement as an alternative. As hiring subsidies are often combined with a preceding short-term training measure within a firm, the authors also asked whether there is an additional advantage of a subsequent subsidy in comparison to short-term training only. While they found positive treatment effects of an additional subsidy, effects are smaller than those from estimates which were not conditional on the participation in a short-term training measure. Furthermore, ZEW et al. (2006) compared similar entries into short subsidization of up to three months before and after the reform and found only minor differences in effectiveness. 
A further study analysed the effects of participation on the labour market prospects of welfare recipients after the Hartz IV reform (Bernhard et al. 2008), focusing on a cohort taking up subsidization in February to April 2005. 20 months after taking up a subsidized job, nearly 70 per cent of recipients were in regular employment. Again, compared to similar unemployed persons, the programme effect amounted to around 40 percentage points. Effects on the prevention of further periods of unemployment and unemployment benefit II receipt were of similar size.

Several studies attempt to take potential deadweight effects into account. A first approach is to investigate the impact of hiring subsidies on the labour market outcomes of formerly unemployed persons, conditional on taking up a job. Thus, suitable comparison persons are chosen by PSM from a group of (formerly unemployed) unsubsidized workers. The underlying idea is that subsidized workers might have been able to find a job without the help of a subsidy, too (thus allowing for deadweight loss), but that the outcome of their employment relationship would have been different. In this sense a lower bound on the effect of subsidies is estimated as the effect of the subsidy on the hiring decision is ignored.

Stephan (2010a) investigated the impact of hiring subsidies on wages, employment rates, and earnings. She focused on individuals in the age group 25 to 49 who took up a subsidized job during the second quarter of 2003. The comparison group consists of similar workers who were hired without the help of a subsidy. First, she showed that subsidized jobs are on average rather low-wage jobs. Second, she found no significant wage differences between subsidized and similar unsubsidized workers, and the difference in individual wage changes was mostly insignificant as well. One main explanation is that the German system of wage setting is shaped by collective contracts and an attachment of wages to jobs rather than to individual abilities. Third, initially subsidized workers subsequently have higher employment rates, resulting in significantly higher earnings during the time frame investigated. Some of the main findings are displayed in Table 3.

Results are similar for separate estimates by industrial sector (Stephan 2010b). Ruppe (2011) found a significant positive relationship between subsidy receipt and tenure, using Cox estimations. The stabilising effect of the subsidy was observed mainly during the first year after taking up the respective job: During a protection period, firms can

Table 3 Accumulated effects of a hiring subsidy on subsidized workers (S) compared to similar unsubsidized workers (U) and average treatment effect on the treated (ATT) during the $\mathbf{3 . 5}$ years after taking-up a job

\begin{tabular}{lcccccc}
\hline & \multicolumn{3}{c}{ Men } & & \multicolumn{3}{c}{ Women } \\
\hline West Germany & $\mathrm{S}$ & $\mathrm{U}$ & ATT & $\mathrm{S}$ & $\mathrm{U}$ & ATT \\
Earnings (in 1000 Euro) & 56.9 & 53.0 & $3.9^{* *}$ & 46.6 & 44.4 & $2.2^{*}$ \\
Employment (in days) & 851 & 781 & $70^{* *}$ & 872 & 808 & $63^{* *}$ \\
Observations & 3060 & 86914 & & 998 & 30488 & \\
\hline East Germany & $\mathrm{S}$ & $\mathrm{U}$ & $\mathrm{ATT}$ & $\mathrm{S}$ & $\mathrm{U}$ & ATT \\
Earnings (in 1000 Euro) & 48.7 & 43.8 & $4.9^{* *}$ & 37.7 & 33.6 & $4.1^{* *}$ \\
Employment (in days) & 906 & 790 & $115^{* *}$ & 908 & 778 & $130^{* *}$ \\
Observations & 3823 & 37003 & & 1522 & 9926 & \\
\hline
\end{tabular}

*) $\left.a=0.05,{ }^{* *}\right) a=0.01$

Source: Stephan (2010a), own computations. 
be asked to reimburse a part of the subsidy if they dismiss workers for reasons attributable to the employer. Using the same data as Stephan (2010a, 2010b), Neubäumer (2012) estimated the relative effects of wage subsidies and further vocational training on the subsequent employment prospects of previously unemployed programme participants. She found that people taking up a subsidized job have the same employment rates as training participants who were hired immediately afterwards. She concludes that firms value training on a subsidized job as much as formal training programmes.

Krug et al. (2008) analysed the impact of firm characteristics on the success of hiring subsidies (for training requirements) and in-work benefits, considering firm characteristics as post treatment variables. They focused on individuals entering employment between May 2002 and August 2003; the outcome variable investigated is the employment status after 18 months. The authors conducted a generalised Oaxaca-Blinder decomposition of the pair wise treatment effects for the matched samples. They found that firm characteristics influenced the success of employment subsidies. In particular, lower average firm wages came along with lower employment rates.

A second approach tackling deadweight effects is instead concerned with the effects of eligibility to participate in a scheme on the labour market prospects of the eligible population. If no effect of schemes on the labour market prospects of the eligible population is found, deadweight loss might be one explanation. Schuenemann et al. (2011) evaluated the BHI scheme (see Section 3.1) for long-term unemployed people, which was in place until 2002. Using data for the period 2000 to 2006, the authors locally estimated the impact of the programme becoming available at the eligibility threshold of 12 months unemployment duration using a regression discontinuity design in differences: The group of eligible people comprises all individuals with at least 12 months of unemployment, whereas the control group consists of all unemployed individuals with at least 11 months of unemployment duration. Furthermore, they conducted a comparison with a period when the programme had already been abolished. Their estimates suggest no significant effects of the subsidy on exit rates out of unemployment, on employment stability, or on employment rates. Results are, however, to effects at the threshold. Moreover, other programmes - like the main hiring subsidy variant (or also job creation schemes) - were available as substitutes for the BHI programme. Thus non-eligibility or the abolition of the BHI programme did not necessarily mean that the control group received less subsidization.

Boockmann et al. (2012) analysed changes in the legislation regarding the hiring subsidies for workers aged 50 or over. In exceptional cases, the subsidy could be granted at up to 70 per cent for up to five years. In 2002, eligibility for the programme - which earlier had covered only the long-term unemployed - was extended to all workers of 50 years of age or over. In 2004, eligibility was again restricted to hard-to-place persons and the duration of the subsidy was cut down to a maximum of three years. The authors used a difference-in-differences estimator to compare changes in transition probabilities between the treatment group (defined as all workers aged 50 to 50 plus six months at the time of entering unemployment) and the comparison group (comprised of slightly younger workers). Significant effects of the changes in conditions were found only for the subgroup of female workers in East Germany. The authors concluded that increases in subsidized employment for all other groups investigated are absorbed by deadweight losses. However, only a comparatively small percentage of individuals in the 
age groups investigated actually received the subsidy, and changes in legislation affected mainly the duration of the subsidy.

Few studies look at the effect of regional wage subsidy policies on regional or firm performance. Estimates of regional panel data for periods before and after the Hartz reforms found that the regional share of ALMP funds devoted to wage subsidies decreased exits out of unemployment as well as entries into unemployment, with an insignificant net effect (Fertig et al. 2006a, Fertig et al. 2006b). Lechner et al. (2013) investigated the relationship between the share of unemployed persons participating in different types of labour market programmes in a firm's hiring region and firm performance for the period 2000 to 2004. However, the authors subsume job creation schemes as well as hiring subsidies in the category "subsidized employment". They concluded that firms do not benefit from a higher exposure to such schemes. Furthermore, they may be even harmed by an increasing regional use of subsidized employment (shrinking, employing a higher share of temporary workers, and having a higher probability of going out of business). They interpreted their results to the effect that such programmes exert negative effects on the competitiveness of unsubsidized firms.

\subsection{Provision of jobs in which participants receive a regular wage The traditional job creation scheme}

A number of pioneering studies by Caliendo, Hujer and Thomsen were concerned with effects of the traditional job creation scheme on the participants' labour market prospects at the start of the millennium. These researchers were the first to analyse this scheme using administrative data. They studied programme inflow in February 2000 and people who were unemployed in January 2000 and met the criteria to enter the scheme. Programme effects on participants were estimated by PSM.

Caliendo et al. (2004; 2008a; 2008b) studied whether participation has distinct effects on participants from different socio-economic groups. They estimated participation effects on the participants' probability to work in regular jobs up to December 2002. Their overall findings were pessimistic: Regarding the broad groups of men and of women in East and West Germany, they found considerable and statistically significant lock-in effects. After the first six to nine months since entering the programme the regular employment rate of participants was more than 20 percentage points lower than for the matched controls for both sexes in West Germany. The corresponding numbers for men and women in East Germany were about 15 and 10 percentage points. Thereafter the effects tended to move slowly towards zero and remained negative except for West German women, who benefit by December 2002 in terms of a positive effect of five percentage points.

Nevertheless, these studies demonstrate that some groups of disadvantaged unemployed people benefit in terms of positive net employment effects in the longer run: Caliendo et al. (2004, 2008a) show that this is the case for long-term unemployed participants in West Germany and female long-term unemployed participants, participants with health restrictions for both regions and genders and West German female participants aged over 50 years. For participants with an unemployment duration of less than 13 weeks, the effects are instead quite detrimental. Caliendo et al. (2008b) found that the effectiveness of the programme tends to increase in a target score defined as the 
number of employment impediments like long-term unemployment and health restrictions of the participants.

Hujer and Thomsen (2010) determined in how far the job creation scheme's effect on participants varied for an entry during the first eight quarters of unemployment duration. They studied the inflow into the scheme in selected months during the years 2000 and 2001. 30 months after programme start, their results imply positive and significant employment effects only for programme entry in the fifth quarter of unemployment duration. For East Germans, the findings suggest no well-determined positive longer-term effects, and for some duration groups even significant negative effects.

Further studies likewise relied on PSM methods: Wunsch and Lechner (2008) on West Germany and Lechner and Wunsch (2009) on East Germany investigated effects of many ALMPs including the traditional job creation scheme. They analysed the inflow into unemployment from 2000 to 2002 and for people aged 25 to 49 years. Programme participants are defined by their first programme participation that started within 18 months after entering unemployment in Wunsch and Lechner (2008) and within three years in Lechner and Wunsch (2009). The analysis consists of a matching step and a regression step that is doubly robust (Wunsch and Lechner 2008: 149). With a negative effect on the regular employment rate even 30 months after entering the programme, both studies found that the traditional job creation scheme was quite detrimental for participants. Stephan and Pahnke (2011) analysed the inflow into different ALMPs in March 2003. Non-participation was defined as waiting, since nonparticipants might have entered a programme after March 2003. The sample was restricted to people aged 25 to 59 years who were initially not yet long-term unemployed. Compared with waiting, the job creation scheme significantly reduced the time spent in regular employment during the 3.5 years after programme entry by 40 (52) days for participations of a duration of 4 to 6 (7 to 12) months, due to lock-in effects. Finally, the evidence suggests some alternative programmes would have worked better for job creation scheme participants, in particular the provision of skills for 7 to 12 months and short in-firm training.

Results are qualitatively similar if bivariate duration models (Abbring and van den Berg 2003) are applied: Hujer and Zeiss (2007) analysed inflow into unemployment in East Germany during the year 2000. They found detrimental participation effects of the traditional job creation scheme on individual exit rates from unemployment into regular employment, in particular just after completing participation.

Even if the subsidies would have led to beneficial effects like increased employability and search effectiveness of the participants (which for most groups, they did not), deadweight loss, substitution and displacements effects might occur (see Section 2). For these reasons some studies aimed at determining effects of the intensity of the programme on the matching efficiency by considering its effects on the regular hiring rate and more general in a Beveridge Curve framework on the job-seeker rate, using regional labour market panel data ${ }^{4}$. The studies by Hujer et al. $(2004,2006)$ used a Beveridge Curve framework for the period of the first quarter of 1999 to the fourth quarter of 2001. Their system GMM estimates for West Germany show a positive though insignificant long-term impact of the number of participants in the job creation scheme relative to the labour force on the job-seeker rate. The findings from a fixed effects regression for the East are no different in qualitative terms. Other 
studies investigated regional panel data for periods around and after the beginning of the millennium; they found either no or detrimental effects of the traditional job creation scheme on outcomes like exit rates of job-seekers into regular jobs or the job-seeker rate (Fertig et al. 2006a, Fertig et al. 2006b, Hagen 2004, Hujer and Zeiss 2005, Hujer et al. 2009).

\section{Wage-paying work opportunities for welfare recipients}

Hohmeyer and Wolff (2010) were the first to study effects of both new work opportunity schemes and of the traditional job creation scheme on labour market prospects of welfare recipients after the introduction of the Hartz IV reform. They analysed the inflow into the programmes from May to July 2005. For all schemes, PSM estimates for the regular employment rate show quite moderate lock-in effects of a few percentage points. After the lock-in period, the estimates imply mostly positive employment effects. They are strongest and already emerge 6 to 12 months after programme entry for work opportunities with regular earnings. The highest effects were observed for East German women at around ten percentage points for most of the second and third year after programme entry and the lowest ones for East German men, at usually less than five percentage points. The positive employment effects of the job creation scheme were more moderate and emerged somewhat later. The lowest employment effects were found for participants of the One-Euro-Jobs scheme. More studies on One-EuroJobs are presented in Section 4.3. Additional estimates showed that wage paying schemes - even in the years after participation was completed - considerably raised annual earnings and reduced former participants' dependence on welfare.

\section{The JobPerspective for welfare recipients}

A comprehensive study by ISG et al. (2011) investigated the JobPerspective. One part of the study investigated participation effects for three inflow cohorts into the subsidized employment phase of JobPerspective between October 2007 and March 2009 and suitable potential controls drawn from administrative data. PSM estimates demonstrated high effects of participation (initially nearly 50 percentage points) on avoiding welfare receipt, which can be attributed to the subsidized employment-take up. The scheme was intended to target people who are harder to place than participants in the traditional job creation scheme or in work opportunities. Therefore, initial (negative) lock-in effects on the regular employment rate of participants of the latter schemes should be considerably stronger than lock-in effects for JobPerspective participants. Yet a comparison of findings of Hohmeyer and Wolff (2010) with those of ISG et al. (2011) suggests the opposite. In addition, ISG et al. (2011) estimated net effects of participation in the employment phase on social inclusion, using survey data of participants in the JobPerspective's employment phase and similar non-participants. The PSM estimates showed that the programme significantly raised the participants' perception of social inclusion and of their households' general living conditions. Figure 2 displays selected results of this analysis.

ISG et al. (2011) were also concerned with aggregate effects of the programme analysing specific company survey data, regional labour market data and an administrative company panel. They found no evidence for displacement effects in companies that did not employ workers subsidized by the JobPerspective. However, 19 per cent of companies responding to a survey replied that at least one of the company's subsidized workers 


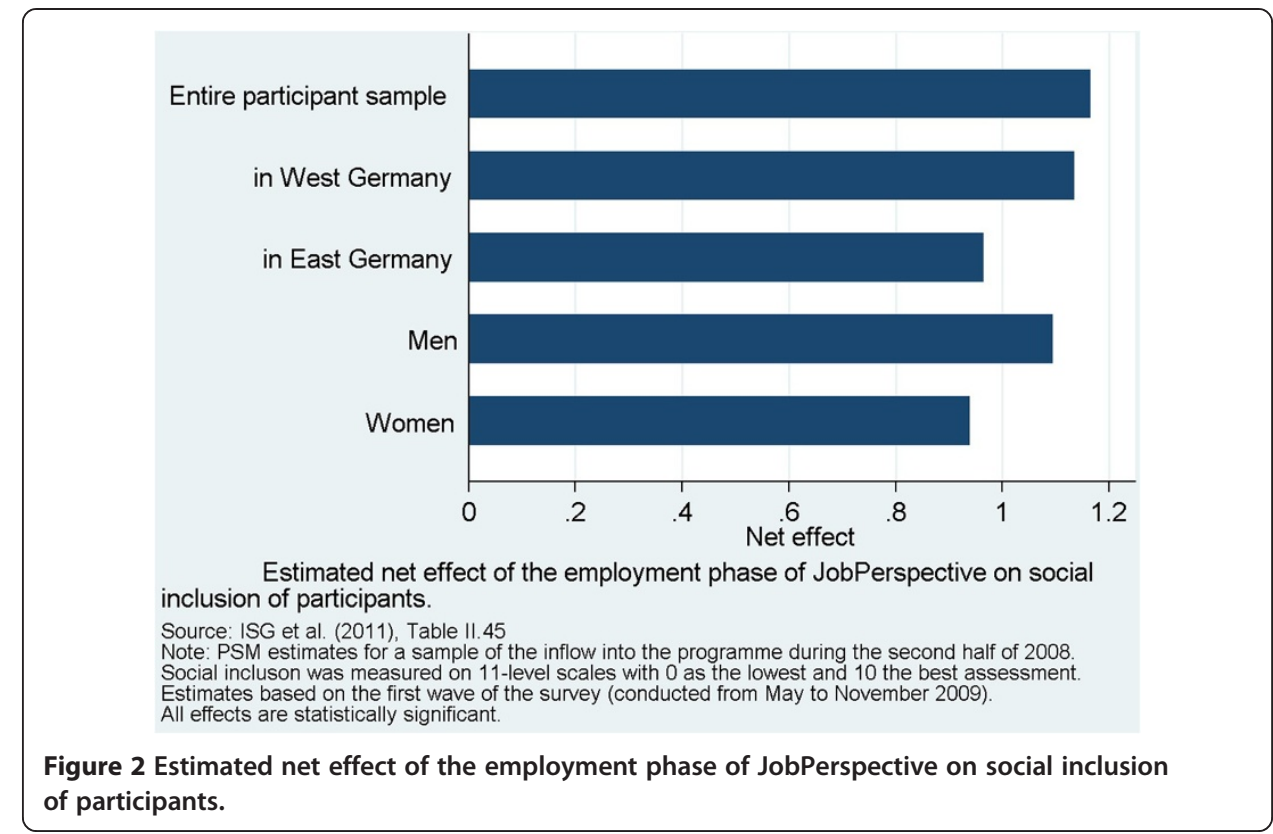

would have been employed regardless of the subsidies, which is some hint at deadweight loss. Additionally the authors studied an administrative panel of the population of German companies; employing at least one worker subsidized by JobPerspective was regarded as a treatment. A difference-in-difference PSM analysis found that this treatment in June 2008 lead to a loss of unsubsidized employment in the treated companies in the West but to an increase in the East. For a treatment in June 2009 these effects were positive in both regions. Moczall (2013) extended this analysis by investigating a longer time horizon for treated establishments in June 2009. His results confirm positive effects on regular employment in West German establishments. But he found no robust effects for East German establishments.

\subsection{Provision of One-Euro-Jobs}

A number of studies investigated how One-Euro-Job participation affects participants' outcomes like working in regular jobs, earnings, welfare benefit receipt and level. All but one study applied PSM to estimate effects on the treated. A first set of studies analysed administrative data and inflow cohorts into the programme just after introducing the Hartz IV reform. The sample in Hohmeyer (2012) and Hohmeyer and Wolff (2012) consists of the entire inflow of unemployed people into One-Euro-Jobs from February to April 2005 and a random sample of the stock of unemployed welfare recipients in January 2005 with no One-Euro-Jobs participation from February to April 2005. Their estimates imply that participation reduces the participants' regular employment rate by a few percentage points (lock-in effects) in the first months after programme start. Moreover, for West German men and women and East German women the results show positive employment effects emerging during the second year after programme entry. These effects were stable and strongest for West German women with values up to three percentage points. Only for East German men were longer-term participation effects negative.

Hohmeyer (2012) estimated effects on regular employment, comparing different One-Euro-Job designs, which varied by planned duration and by weekly working time. 
Due to a short observation window of up to 28 months after programme entry, her results for men and women in East and West Germany can provide only limited evidence on an optimal length of participation. Pair wise comparisons show that for East German men participation durations of up to 4 months would be preferable to longer ones of more than 4 up to 8 , and more than 8 up to 12 months. However, compared with waiting it would have been even better not to treat East German men at all or reduce participant numbers and change their composition, in order to limit participation to welfare recipients in need of this type of support. Furthermore, Hohmeyer (2012) did not find stronger lock-in effects for longer working hours. Also, after completing participation, the results suggest that there are hardly any differences in effectiveness between the regarded working hour groups, with one exception: For a 21 to 29 hour working week and East German women, the estimates imply positive employment effects compared with waiting and compared with working less or more.

Hohmeyer and Wolff (2012) analysed the effects of One-Euro-Job participation for different socio-demographic groups. They found partly negative employment effects or near zero longer term effects for welfare recipients aged younger than 25 years and welfare recipients whose last job ended during the year prior to programme start. In contrast, positive employment effects were found to be relatively strong for some older age-groups and for people who for more than one year were not regularly employed.

Using survey data, Huber et al (2011) studied One-Euro-Jobbers who started their participation between November 2006 and March 2007 for up to nine months after programme start. Thomsen and Walter (2010) used administrative data to analyse people who entered welfare in 2006 and estimated effects of the first One-Euro-Job that they entered for six up to 12 months after programme start. They further distinguished between immigrants and Germans. Both studies estimated effects for short periods after programme entry, so they mainly investigated the participation period and a short catch-up period thereafter. For these short periods, their PSM estimates suggest no beneficial participation effects.

Zabel (2013) was interested in the effects of One-Euro-Jobs and other programmes on the employment prospects of lone mothers. She analysed women who started a period of welfare receipt without employment between October 2005 and December 2007, using a timing-of-events approach. Her results suggest beneficial effects of OneEuro-Jobs for mothers with a partner as well as for childless single women. The same holds for lone mothers in East Germany and partly in West Germany with one exception: The employment prospects of West German lone mothers whose youngest child is three to five years old do not improve by participation. This latter result might be due to insufficient child care facilities in West Germany.

Some studies provided insights into effects on other important outcomes. Wulfgramm (2011a, 2011b) investigated the relationship between One-Euro-Job participation and selfreported life satisfaction as well as social inclusion, using data from the household panel Labour Market and Social Security. She applied methods for ordered dependent variables as well as regression and fixed effects regression models. According to her results, OneEuro-Job participation is better than open unemployment both in terms of life satisfaction and social inclusion. Past One-Euro-Job participation did not affect these outcomes. However, the analysis did not attempt to estimate causal effects. 
Companies that employ One-Euro-Jobbers might therefore employ less people in regular jobs. Policy-makers would like to prevent this. Therefore, the tasks of OneEuro-Jobbers should not be the same as those of regularly employed people in a company. A qualitative study of Klemm, Sowa and Freier (2012) among other things regarded the job contents and tasks performed. They pointed out some of the main fields like care (for children or the elderly) sectors, manual or technical jobs in municipalities, social initiatives and organizations, or manual work in shop floors. Moreover, they discussed examples of One-Euro-Jobs, in which participants performed at least partly regular task like cooking meals for children in a childcare centre. Analysing an establishment survey, Kettner and Rebien (2007) found that One-Euro-Jobbers in about a quarter of the establishments perform tasks that do not differ from those of regularly employed colleagues. Using another establishment survey, Hohendanner (2011) compared establishments employing One-Euro-Jobbers with similar establishments that do not employ One-Euro-Jobbers based on PSM. As an outcome he chose a before and after treatment difference of the stock of contributory employed workers within a company (to control for unobserved company specific effects). The results for the periods 2004 to 2006 and 2004 to 2007 imply no well determined effects of One-Euro-Jobs on the contributory jobs outcome. Hohendanner also investigated whether One-Euro-Jobs lead to displacement effects in companies that do not employ One-Euro-Jobbers, due to distorted competition. The results stem from a panel regression model analysing the employment change of companies who do not employ One-Euro-Jobbers and controlling for One-Euro-Jobber stock in the same region and sector. He found no evidence for displacement effects.

\section{Lessons learnt}

In Germany, subsidized work schemes are important ALMPs. Over the last decade, evaluation studies have added a lot of new insights on what works and what does not. As no field experiments had been conducted, however, researchers - and thus policy makers - relied on results from non-experimental studies.

For hiring subsidies aimed at unemployed persons with placement difficulties, early studies comparing subsidized and similar unsubsidized unemployed persons faced the problem that it is not possible to disentangle the effect of subsidies on taking up a job and on labour market results conditional on getting employed. Large estimated effects of around 40 percentage points higher employment rates of the subsidized - thus present a mixture of both effects. Nonetheless, even conditioning on employment, hiring subsidies on average positively influence tenure and cumulated earnings of initially subsidized persons. Studies analysing the effects of becoming eligible, however, did not find significant effects on labour market outcomes of the treatment group.

Regarding job creation schemes, studies for the period before the Hartz reforms found on average negative employment effects for the traditional scheme for broad groups of participants. They presumably resulted from stigma effects and creaming: Programme participants were not as hard-to-place as had been intended by the legislative authority. However, one important result characterised the studies: Positive and sometimes remarkable employment effects can be achieved for unemployed people with severe difficulties of finding regular jobs. The findings for long-term unemployed participants and people with health restrictions imply this. In turn, policy-makers 
should target such programmes at the most vulnerable groups, and the PES should implement the schemes mainly for unemployed people with severe employment impediments. The evidence on effects of such programmes for disadvantaged welfare recipients after the Hartz reforms also suggests that such a strategy might lead to positive employment effects.

The rather beneficial employment effects of different public job creation schemes for welfare recipients after the Hartz reforms might also stem from an increased pressure on the unemployed to find jobs, though. Participants might to a larger extent exploit gains in employability that stem from their participation. Moreover, the schemes were also designed in a way that left a considerable incentive to take up regular jobs. Results from studies that quantify effects of the job creation schemes on a regional or company level are still relatively limited. They find no or detrimental effects of the traditional job creation scheme prior to 2005. However, more studies are needed to clarify to what extent the results from this literature are stable in different periods and for different policies.

Regarding policy reactions, abolishing the traditional job creation scheme in April 2012 seems relatively reasonable in light of the evaluation results: By that time the scheme was available to unemployment insurance recipients, many of whom are not characterised by severe employment impediments. Unemployed welfare recipients are still eligible for One-Euro-Jobs and the new promotion of employment relationships. However, it would have been better to let placement constraints and not the type of benefit receipt determine eligibility to schemes of public employment provision. Even some unemployment insurance recipients are hard to place and in extreme cases have to wait for two years (UB I recipients aged at least 58 years) before they run out of UB I and might qualify for welfare and in turn for job creation participation. Another important lesson learnt from evaluation studies was that job creation schemes might be particularly harmful for young unemployed persons. Since April 2012 the previous requirement to quickly place young UB II recipients into One-Euro-Jobs, if they could not be immediately placed into regular jobs or training has therefore been abolished.

Some open questions remain. For instance, several studies show that estimated treatment effects vary across subgroups (for instance region or gender) and time periods. Little is known, however, on the reasons behind such differences. Only few studies analyse programme effects on social inclusion or employability, and no study analyses programme effects on the labour market results of other household members. There is only meagre evidence on aggregate effects and on deadweight loss, substitution or displacement effects. Moreover, One-Euro-Jobs do not provide participants with (much) additional income. This programme might therefore have threat effects, a topic which has not yet been investigated. Convincing cost-benefit analyses of the schemes are still missing. They would also require estimates of unintended effects, of the value of additionally produced goods, and of the value of social inclusion.

Finally, an important question is whether other countries can learn from the German experience. Most OECD countries utilize some kind of employment incentives and direct job creation schemes (OECD 2013, Table P and Q). Numerous studies have investigated the effect of hiring subsidies on the labour market outcomes of subsidized workers for countries as Sweden, Belgium, and the UK (e.g. Carling and Richardson 2004, Cockx et al. 1998, Dorsett, 2006, Fredriksson and Johansson 2008, Sianesi 2008). 
The German results indicate that an important positive effect of subsidies is that they stabilize employment. This is probably due to the design of the German scheme, as firms can be required to reimburse part of the subsidy for dismissing initially subsidized workers during an associated protection period. It might be worthwhile for policy makers in other countries to consider adapting this design when implementing or re-designing wage subsidy schemes. For direct job creation programmes, the German experience clearly shows a) the importance of a careful targeting of participants and b) the particular dangers of placing young welfare benefit recipients in these schemes. These are also lessons that should be of interest for policy makers from countries other than Germany.

\section{Endnotes}

${ }^{1}$ The expression unemployment benefit II is misleading, as the benefit is not conditional on unemployment but on insufficient income to meet basic needs of the household members. Welfare recipients could well be in training or work.

${ }^{2}$ The benefit formula had one part that during the first two years after exhausting UB I was still earnings related, with a low upper cap. This earnings related part was abolished in July 2011.

${ }^{3}$ For social assistance recipients similar work opportunity programmes were in force before the Hartz IV reform, but no impact studies and no solid descriptive statistics on these programmes are available.

${ }^{4}$ The studies usually defined job-seekers as unemployed people and participants in ALMPs.

Competing interests

The Institute for Employment Research conducts independent research. It is funded by the German Federal Employment Agency and the German Federal Ministry of Labour and Social Affairs. The IZA Journal of Labor Policy is committed to the IZA Guiding Principles of Research Integrity. The authors declare that they have observed these principles.

\section{Acknowledgements}

We are extremely grateful to Cordula Zabel and to an anonymous referee for very helpful remarks. Moreover, we would like to thank Santa Donhauser for preparing the aggregate data on programme expenditures.

Responsible editor: Juan F Jimeno

\section{Author details}

${ }^{1}$ Institute for Employment Research, Regensburger Str. 104, 90478 Nuremberg, Germany. ${ }^{2}$ Institute for Employment Research, University of Erlangen-Nuremberg, and IZA, Regensburger Str. 104, 90478, Nuremberg, Germany.

Received: 24 September 2013 Accepted: 28 October 2013

Published: 16 December 2013

References

Abbring JH, van den Berg GJ (2003) The nonparametric identification of treatment effects in duration models. Econom 71:1491-1517

Adda J, Costa Dias M, Meghir C, Sianesi B (2007) Labour market programmes and labour market outcomes: a study of the Swedish active labour market interventions. IFAU-working paper No. 2007:27, Uppsala

Arellano M, Bond S (1991) Some tests of specification for panel data: Monte Carlo evidence and an application to employment equations. Rev Econ Stud 58:277-297

Bell B, Blundell R, Van Reenen J (1999) Getting the unemployed back to work: the role of targeted wage subsidies. Int Tax Public Finance 6:339-360

Bernhard S, Gartner H, Stephan G (2008) Wage subsidies for needy job-seekers and their effect on individual labour market outcomes after the German reforms. Institute for Employment Research discussion paper No. 21/2008, Nuremberg

Blos K, Rudolph H (2005) Simulationsrechnungen zum Arbeitslosengeld II: Verlierer, aber auch Gewinner. IAB-Kurzbericht 17/2005, Nuremberg

Blundell RW, Bond SR (1998) Initial conditions and moment restrictions in dynamic panel data models. J Econom 87:115-143 
Boockmann B, Zwick T, Ammermüller A, Maier M (2012) Do hiring subsidies reduce unemployment among older workers? Evidence from two natural experiments. J Eur Econ Assoc 10:735-764

Brussig M, Schwarzkopf M (2011) Eingliederungszuschüsse als Instrument der Arbeitsmarktpolitik: Eine Implementationsstudie, IAB-Bibliothek 329. Bielefeld: Bertelsmann, Nuremberg

Brussig M, Bernhard S, Jaenichen U (2008) Die Reform der Eingliederungszuschüsse durch Hartz III und ihre Auswirkungen für die Förderung von Arbeitslosen. Soz Fortschr 57:66-75

Caliendo M, Hujer R, Thomsen SL (2004) Evaluation der Eingliederungseffekte von Arbeitsbeschaffungsmaßnahmen in reguläre Beschäftigung für Teilnehmer in Deutschland. J Labour Mark Res 37:211-237

Caliendo M, Hujer R, Thomsen SL (2008a) The employment effects of Job creation schemes in Germany - a microeconometric evaluation. In: Millimet D, Smith J, Vytlacil E (eds) Advances in econometrics: modelling and evaluating treatment effects in econometrics, vol 21, pp 381-428

Caliendo M, Hujer R, Thomsen SL (2008b) Identifying effect heterogeneity to improve the efficiency of job creation schemes in Germany. Appl Econ 20:1101-1122

Calmfors L (1994) Active labour market policy and unemployment - a framework for the analysis of crucial design features. OECD Labour Market and Social Policy Occasional Paper 15, Paris

Card D, Kluve J, Weber A (2010) Active labor market policy evaluations: a meta-analysis. Econ J 120:F452-F477

Carling K, Richardson K (2004) The relative efficiency of labour market programs: Swedish experience from the 1990s. Labour Econ 11:335-354

Cichorek A, Koch S, Walwei U (2005) Arbeitslosengeld II: Erschweren "Zusatzjobs" die Aufnahme einer regulären Beschäftigung? IAB-Kurzbericht 08/2005, Nuremberg

Cockx B, Van der Linden B, Karaa A (1998) Active labour market policies and job tenure. Oxford Econ Papers 10:685-708

Dorner M, Heining J, Jacobebbinghaus P, Seth S (2010) The sample of integrated labour market biographies. J Appl Soc Sci Stud 130:599-608

Dorsett R (2006) The new deal for young people: effects on the labour market status of young Men. Labour Econ 13:405-422

Fay RG (1996) Enhancing the effectiveness of active labour market policies: evidence from programme evaluations in OECD countries. OECD Occasional Papers 18, Paris

Fertig M, Kluve J, Schmidt CM (2006a) Die makroökonomische Wirkung aktiver Arbeitsmarktpolitik - eine Panelanalyse auf Ebene regionaler Arbeitsmärkte. J Labour Mark Res 39:575-601

Fertig M, Schmidt CM, Schneider H (2006b) Active labor market policy in Germany-Is there a successful policy strategy? Reg Sci Urban Econ 36:399-430

Fredriksson P, Johansson P (2008) Dynamic treatment assignment - the consequences for evaluations using observational data. J Business Econ Stat 26:435-445

Hagen T (2004) Ökonometrische Evaluation der aktiven Arbeitsmarktpolitik in Ostdeutschland auf Basis von Regionaldaten - Grundlegende Probleme und Ergebnisse dreier Ansätze. Z für Eval 2004:241-263

Hartmann J (2004) Lohnkostenzuschüsse und Integration schwer vermittelbarer Personen in den ersten Arbeitsmarkt. Beiträge zur Arbeitsmarkt- und Beruffforschung 284, Nuremberg

Hohendanner C (2011) One-euro-jobs and regular employment - an analysis of potential substitution effects using the IAB establishment panel. J Econ Stat 231:210-246

Hohmeyer K (2012) Effectiveness of one-euro-jobs: do programme characteristics matter? Appl Econ 44:4469-4484

Hohmeyer K, Wolff J (2010) Direct job creation in Germany revisited: Is it effective for welfare recipients and does it matter whether participants receive a wage? Institute for Employment Research discussion paper No. 21/2010, Nuremberg

Hohmeyer K, Wolff J (2012) A fistful of Euros, Does One-Euro-Job participation lead means-tested benefit recipients into regular jobs and out of unemployment benefit II receipt? Int J Soc Welf 21:174-185

Hsiao C, Pesaran M, Tahmiscioglu A (2002) Maximum likelihood estimation of fixed effects dynamic panel data models covering short time periods. J Econom 109:107-150

Huber M, Lechner M, Wunsch C, Walter T (2011) Do German welfare-to-work programmes reduce welfare dependency and increase employment? Ger Econ Rev 12:182-204

Hujer R, Thomsen SL (2010) How do the employment effects of job creation schemes differ with respect to the foregoing unemployment duration? Labour Econ 17:38-51

Hujer R, Zeiss C (2005) Macroeconomic impacts of Job creation schemes on the matching process in West Germany. Appl Econ Q 51(2):203-217

Hujer R, Zeiss C (2007) The effects of job creation schemes on the unemployment duration in Eastern Germany. J Labour Mark Res 40:383-398

Hujer R, Caliendo M, Zeiss C (2004) Macroeconometric evaluation of active labour-market policy - a case study for Germany. In: Descy P, Tessaring M (eds) Impact of education and training (Third report on vocational training research in Europe). Office for Official Publications of the European Communities, Luxemburg, pp 179-214

Hujer R, Blien U, Caliendo M, Zeiss C (2006) Macroeconometric Evaluation of Active Labour Market Policies in Germany - A Dynamic Panel Approach Using Regional Data. In: Caroleo FE, Destefanis S (eds) The European Labour Market - Regional Dimensions. Physica Verlag, Frankfurt/Main, pp 287-310

Hujer R, Rodrigues PJM, Wolf K (2009) Estimating the macroeconomic effects of active labour market policies using spatial econometric methods. Int J Manpow 30:648-671

Imbens GW, Angrist JD (1994) Identification and Estimation of Local Average Treatment Effects. Econom 62:446-475

ISG, IAB, RWI (2011) Endbericht der Evaluation der Leistungen zur Beschäftigungsförderung nach § 16e Absatz 10 des Zweiten Buches Sozialgesetzbuch. Bundestagsdrucksache 17/6880, Berlin

Jacobi L, Kluve J (2007) Before and after the Hartz reforms: The performance of active labour market policy in Germany. J Labour Mark Res 40:45-64

Jaenichen U (2002) Lohnkostenzuschüsse und individuelle Arbeitslosigkeit. Mitteilungen aus der Arbeitsmarkt- und Berufsforschung 35:327-351 
Jaenichen U (2005) Lohnkostenzuschüsse und individuelle Beschäftigungschancen. In: Bellmann L, Hübler O, Meyer W, Stephan G (eds) Löhne, Institutionen und Beschäftigung, Beiträge zur Arbeitsmarkt- und Berufsforschung 294, Nuremberg, pp 137-156

Jaenichen U, Stephan G (2011) The Effectiveness of Targeted Wage Subsidies for Hard-to-Place Workers. Appl Econ 43:1209-1225

Kettner A, Rebien M (2007) Soziale Arbeitsgelegenheiten - Einsatz und Wirkungsweise aus betrieblicher und arbeitsmarktpolitischer Perspektive. Institute for Employment Research Forschungsbericht 2/2007, Nuremberg

Klemm M, Sowa F, Freier C (2012) Ein-Euro-Jobs in Deutschland. Fallstudien zur Auswirkung der SGB-II-Arbeitsgelegenheiten auf Beschäftigungsstruktur und Arbeitsmarktverhalten von Organisationen. Institute for Employment Research Forschungsbericht 15/2012, Nuremberg

Kluve J (2010) The effectiveness of European active labor market programs. Labour Econ 17:904-918

Krug G, Dietz M, Ullrich B (2008) The impact of firm characteristics on the success of employment subsidies - a decomposition analysis of treatment effects. Institute for Employment Research discussion paper No. 18/2008, Nuremberg

Lechner M, Wunsch C (2009) Active labour market policy in East Germany: waiting for the economy to take off. Econ of Transit 17:661-702

Lechner M, Scioch P, Wunsch C (2013) Do firms benefit from active labour market policies? IZA discussion paper No. 7614, Bonn

Moczall A (2013) Subsidies for substitutes? New evidence on deadweight loss and substitution effects of a wage subsidy for hard-to-place job-seekers. Institute for Employment Research discussion paper No. 05/2013, Nuremberg

Müller K-U, Steiner V (2009) Would a legal minimum wage reduce poverty? A micro-simulation study for Germany. J Income Distrib 18:131-151

Neubäumer R (2012) Bringing the unemployed back to work in Germany: training programs or wage subsidies? Int J Manpow 33:159-177

OECD (2013) Employment outlook, statistical annex, Paris

Pissarides CA (2000) Equilibrium unemployment theory. The MIT Press, Cambridge

Rosenbaum PR, Rubin DB (1983) The central role of the propensity score in observational studies for causal effects. Biometrika 70:41-55

Rubin DB (1974) Estimating causal effects of treatments in randomized and non-randomized studies. J Educ Psychol 66:688-701

Ruppe K (2011) Eingliederungszuschüsse und Betriebszugehörigkeit in Westdeutschland. Soz Fortschr 60:231-239

Schuenemann B, Lechner M, Wunsch C (2011) Do long-term unemployed workers benefit from targeted wage subsidies. Economics working paper series 1126. University of St Gallen, School of Economics and Political Science, St. Gallen

Sianesi B (2008) Differential effects of active labour market programs for the unemployed. Labour Econ 15:392-421

Stephan G (2010a) Employer wage subsidies and wages in Germany - some evidence from individual data. J Labour Mark Res 43:53-71

Stephan G (2010b) Wages, employment and tenure of temporarily subsidized workers: does the industry matter? Institute for Employment Research discussion paper No. 12/2010, Nuremberg

Stephan G, Pahnke A (2011) The relative effectiveness of selected active labor market programs. An empirical investigation for Germany. Manch Sch 79:1262-1293

Thomsen SL, Walter T (2010) Temporary extra jobs for immigrants: merging lane to employment or dead-end road in welfare? Labour 24:114-140

Wulfgramm M (2011a) Can activating labour market policy offset the detrimental life satisfaction effect of unemployment? Socio-Econ Rev 9:477-501

Wulfgramm M (2011b) Subjektive Auswirkungen aktivierender Arbeitsmarktpolitik. Ein-Euro-Jobs als sozialintegrative Massnahme? Z für Sozialreform 57:175-197

Wunsch C, Lechner M (2008) What did all the money do? On the general ineffectiveness of recent West German labour market programmes. Kyklos 61:134-174

Zabel C (2013) Does activation increase lone mothers' employment chances? Effects of training and workfare for lone mothers receiving means-tested benefits in Germany. Int J Sociolog Soc Policy 33:453-473

ZEW, IAB, IAT (2006) Endbericht "Modul 1d, Eingliederungszuschüsse und Entgeltsicherung" im Rahmen der Evaluation der Maßnahmen zur Umsetzung der Vorschläge der Hartz-Kommission. Forschungsbericht F348/4, German Federal Ministry of Labour and Social Affairs, Berlin

doi:10.1186/2193-9004-2-16

Cite this article as: Wolff and Stephan: Subsidized work before and after the German Hartz reforms: design of major schemes, evaluation results and lessons learnt. IZA Journal of Labor Policy 2013 2:16. 